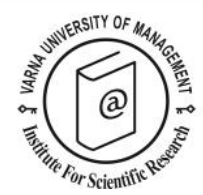

\title{
The symmetric and asymmetric impacts of cognitive attitude components on overall mass tourism destination image: gender comparison
}

\author{
Demet Ceylan¹, Beykan Cizel² and Hatice Karakaş3*
}

\footnotetext{
1 School of Tourism and Hospitality Management, Antalya Bilim University, Antalya, Turkey. E-mail: demet.ceylan@antalya.edu.tr

${ }^{2}$ Tourism Faculty, Akdeniz University, Antalya, Turkey. E-mail: beykan@akdeniz.edu.tr

3 Tourism Faculty, Akdeniz University, Antalya, Turkey. E-mail: haticekarakas@akdeniz.edu.tr

* Corresponding author
}

\begin{abstract}
Mass tourism has become the preferred travel type for millions of people. All-inclusive (AI) initially emerged as an accommodation type for mass tourism destinations but has evolved to become its own form of tourism. Factors motivating tourists towards a mass-tourism destination offering all-inclusive products may vary according to market segments and demographic attributes. Research shows that cognitive factors that affect a destination's image, which is one factor that attracts tourists, are not symmetrical in all cases. This study examines the effect of cognitive attitude components on the general destination image perception of tourists by using Asymmetric Impact-Performance Analysis (AIPA) to assess Antalya, a prominent AI mass-tourism destination. Regression analysis results provide important insights for destination management organisations (DMO) by classifying the asymmetric effects of each destination's cognitive attitude component on overall destination image perception, according to gender.
\end{abstract}

Keywords: Destination Image, Cognitive Attitude, Three-Factor Theory, Gender, All-Inclusive Mass Tourism

Citation: Ceylan, D., Cizel, B. and Karakaș, H. (2021). The symmetric and asymmetric impacts of cognitive attitude components on overall mass tourism destination image: gender comparison. European Journal of Tourism Research 28, 2805 . 


\section{Introduction.}

Understanding tourist image perception towards a tourist destination is crucial for assuring competitiveness. Destination image measurement identifies the strengths and weaknesses of destinations and enhance strategies that tourism destinations can implement to optimise their potential (Pike \& Ryan, 2004; Russel \& Pratt, 1980; Stylos et al., 2016 \& 2017; Stylidis et al., 2017).

Public and private entities responsible for destination management examine cognitive attributes that affect tourists' perceptions of a destination, determine which of these attributes most affect overall destination image and dedicate limited resources to further improve these attributes, and while many factors have an impact on overall destination image, the effects of each attribute are beyond the scope of this study.

Asymmetric relationships between product attributes and overall customer satisfaction, and classification of product attributes in terms of these relationships have been considered in many research areas, especially marketing and consumer behaviour (Albayrak \& Caber, 2013; Litvin \& Ling, 2001; Matzler et al., 2004; Mittal et al., 1998; Truong \& King, 2009). The literature reveals a limited number of studies that examine the cognitive attributes of destination image and their effects on overall destination image, and classify differences based on gender. In the light of the relevant literature, this study aims to answer the question, 'Do destination image perceptions differ according to gender?'.

The research model is based on the assumption that the relationship between performance and satisfaction in attracting tourists to a destination are non-linear (Matzler \& Sauerwein, 2002) and can be classified as basic performance and excitement factors, according to the asymmetric effects of product and destination attributes on overall satisfaction (Kano et al., 1984). Three-Factor Theory is utilised to classify research findings.

This study has three objectives, considering the literature gap and research question:

(1) identifying outstanding cognitive attributes affecting the overall destination image perception of tourists for a mass tourism destination offering AI products;

(2) assessing symmetric and asymmetric effects of these cognitive attributes on overall destination image perception, according to gender;

(3) classifying asymmetric effects of cognitive destination attributes on overall destination image, according to gender.

To achieve these objectives, the paper is designed as follows. First, a summary of literature considering destination image, cognitive factors influencing destination image perception, and AI Mass Tourism is presented. Afterwards, symmetric and asymmetric effects of cognitive destination attributes on tourists' overall destination image perceptions are analysed and classified, according to gender, by using ThreeFactor Theory. Before presenting research findings, brief information is provided about Antalya, the research setting. Finally, the article provides a discussion concerning the managerial implications of research findings.

\section{Cognitive Attributes Affecting Destination Image Perception}

Kotler (2002) argues that destination image is based on a person's beliefs, ideas, feelings, expectations and impressions. Baloglu and McLeary (1999), on the other hand, define destination image as an attitude construct that includes an individual's knowledge, emotions and overall impression of an object or destination. 
There are different approaches used in destination image measurement (Pearce, 2005). One method asks tourists to assess the visual, tactile, sensory and auditory elements of a destination by using openended questions. An alternative method uses cognitive maps drawn by tourists about a destination. However, researchers often prefer measuring destination image perception based on three interrelated attitude components: cognitive, affective and conative (Aranson et al., 2010; Ceylan \& Çizel, 2018; Hilgard, 1980; Gartner, 1993; Pike, 2009; Pike \& Ryan, 2004).

The conative component is often positioned as a target variable by researchers and is defined as the total result of cognitive and affective components (Baloglu et al., 2004; Stylidis et al., 2017; Stylos \& Bellou, 2018; Zhang et al., 2018). The affective component is a mediator rather than an independent image perception generator (Agapito et al., 2013; Gursoy et al., 2014). Consensus holds that the cognitive component both affects overall image perception directly and indirectly via the affective component. Therefore, cognitive components are considered to be the root of overall image formation (Anand et al., 1988; Beerli \& Martín, 2004a, 2004b; Stern \& Krakover, 1993; Stylidis et al., 2017).

Crompton's description of the overall image (1977) - arranged representations of a destination in a cognitive system - indicates the importance of cognitive components. Many destination image studies have analysed cognitive perceptions focusing on the concrete attributes of a destination (Agapito et al., 2013; Beerli \& Martin, 2004a, 2004b; Gartner, 1989; Lee \& Lee, 2009; Lin et al., 2018; Pearce, 1982; Pike, 2002; Stylidis et al., 2017; Stylos et al., 2016, 2017). In the reviewed literature, cognitive destination image attributes are grouped into five factors: natural resources, general and tourism infrastructure, economic and political elements, tourist attraction, and social environment (Beerli \& Martin, 2004; Stylos et al., 2016, 2017; Stylidis et al., 2017), and these attributes differ according to destination and tourism type (Beerli \& Martin, 2004; Smith et al., 2015; Stylidis et al., 2017; Stylos et al., 2016, 2017). Furthermore, researchers suggest that the perception of overall image may differ according to demographic factors like nationality and gender (Baloğlu et al., 2004; Ceylan \& Çizel, 2018).

The Multivariate Regression Analysis used in this study reveals both the linear and nonlinear effects of each cognitive component on overall destination image perception for AI, mass tourism destinations. The results of the study present the strengths and weaknesses of Antalya as a tourism destination and may provide insights for developing strategies that ensure the optimal use of resources (Stylos et al., 2016, 2017; Stylidis et al., 2017).

\section{All-Inclusive System as a Type of Mass Tourism}

To gain a deeper understanding, mass tourism discussions should cover spatial, social, economic and historical perspectives (Andrews, 2005). Furthermore, mass tourism research should be studied geographically to find how tourism experiences are intertwined with social and culturally constructed meanings (Rakic \& Chambers, 2012).

All-inclusive (AI), emerged as a form of accommodation in the 1960s and is widely regarded as the type of mass tourism that creates the atmosphere offered in many tourism destinations around the world (Çizel et al., 2013). AI systems offer holiday packages (e.g. accommodation, transportation, food and beverage, entertainment and sports activities) to tourists at a fixed price (Bowen, 2001). In the context of international tourism, AI is considered an important product innovation, which is a demand generator in and of itself (Issa \& Jayawardena, 2003; Poon, 1998).

AI is a standardised, quality-controlled and economic holiday product that includes the minimum requirements for a holiday, making it preferred by the masses (Heung \& Chu, 2000). AI is a useful system 
in tourism that eliminates surprises for tourists and unexpected costs for the suppliers, and thus offers consistency (Issa \& Jayawardena, 2003) and reduces transport, hygiene and security risks in less-known destinations (Issa \& Jayawardena, 2003; Wong \& Kwong, 2004).

Literature about AI as a type of mass tourism product typically revolves around sociological, anthropological and geographical discussions that focus on production, consumption and spatial characteristics of mass tourism (Birkan, 2004; Çizel et al., 2013; Menekșe, 2005; Poon, 2003; Üner et al., 2007; Vainikka, 2013; Voss, 2003). Despite the increase in demand for AI, the literature does not provide studies about factors affecting tourist attitudes and perceptions of destinations offering special masstourism products like AI. If mass tourism destinations do not pay attention to the attributes that affect attitudes towards their overall destination image, they may not optimally benefit from economic and social outcomes of tourism and may become less competitive over time.

Mass tourism is seen as a distinct form of tourism that can be distinguished from others based on mass production, mass consumption and its connection to mass tourism centres. Poon (2003) defines mass tourism as tourism that is standardised, packaged, mass-produced, is widely marketed to customers and consumed collectively by tourists without considering local norms or cultures. Mass tourism production has become standardised and institutionalised in connection with Fordism, controlled by large-scale tour operators (Cohen, 1972). It is stated that the quality of mass tourism is culturally poor and commoditised due to the type of production and product, leading to homogenisation and standardisation of tourist experiences at the expense of individualism (Ash \& Turner, 1976: Poon, 1993). Mass tourists are classified and organised according to individual mass-tourist typologies (Cohen, 1972; Smith, 1977). Organised mass tourists are constrained by their group's itinerary, whereas individualised mass tourism allows for some control over one's itinerary (Cohen, 1972). Mass tourism represents largescale developments, as opposed to small-scale, alternative development (Bramwell, 2004; Gursoy et al., 2010), and may represent a holiday package with many activities (such as AI) beyond sand, sun and sea. Package tours have become integrated products with complex, complementary services and unique features (Aguiló et al., 2005; Poon, 2003). AI as a type of mass tourism is not actually a new application. It was first offered in Majorca, Spain during the mid-1950s and the system, which is based on the application of a single, predetermined price for tourism activities (Poon, 1998) has attracted more attention with each passing year. Since the 1950s, German and British source market outbound tour operators have continued to promote and spread AI (Demir \& Demir, 2001; Issa \& Jayawardena, 2003).

\section{The case of Antalya, Turkey as an All-Inclusive Tourism Destination}

Increasing tourist interest in the AI system, beginning in the 1980s, and pressure on large-scale tour operators led to the implementation of AI at tourism destinations (Çizel et al., 2013) in Spain, Turkey, Greece and Thailand. During the 1980s, AI showed great development in Turkey with the establishment of chain hotels like Marco Polo, Magic Life, Robinson Club and Club Med, and has become a preferred tourism product, especially in destinations like Antalya, Bodrum and Marmaris (Çizel et al., 2013). Turkey has benefited from AI capabilities and has become one of the best AI product providers with the most widespread application in coastline destinations in Turkey (Birkan, 2004). Despite several difficulties experienced throughout Europe, since 1999 Turkey has experienced an upward trend in tourism, based on AI administration (Ostermaier, 2003). Research shows that $85 \%$ of German tourists coming to holiday in Turkey prefer it due to AI product offerings (Üngüren et al., 2009). Successful implementation of the AI system in Turkey has led to a reconsideration of AI products and systems in competing countries like Spain (Menekșe, 2005). AI packages have become one of the most important weapons for Turkey in world tourism. In the past 30 years, Turkey has risen to higher ranks and has become one of the most important AI tourism providers in the world, and Antalya has been recognised 
as the best practitioner of the system. The share of tourism in Turkey's GDP has grown from $0.5 \%$ in the 1970 to $2.1 \%$ in the 1990 and reached to $3.8 \%$ in 2018, in line with AI tourism development (Ministry of Culture \& Tourism, 2020).

Antalya is the most important tourism city and destination in Turkey. Natural resources, tourist attractions, various types of accommodation facilities and wide transportation network integration are the primary factors influencing tourism development in the Antalya region. It is evident that Antalya is the tourism capital of Turkey, with 13,057,000 tourists representing $28 \%$ of total international arrivals in 2018 and bearing $54 \%$ of bed capacity and 31\% of infrastructure investments in Turkey (Ministry of Culture \& Tourism, 2020).

The ongoing dispute over the definition of AI packages in the world and Turkey has led to several package titles, including Classic, Imperial, Maximum, Ultra and High Class, depending on the products and services included in a package. In general, AI packages include accommodation, meals, snacks, alcoholic and soft beverages, entertainment, sports and fitness activities, kids club and a spa (Uner et al., 2006). AI packages offered in Antalya constitute a wide variety, reflecting global trends. As an example, variations between different AI packages include local and imported alcoholic beverages, whereas the classic AI package does not include imported alcoholic beverages. Antalya has been deemed one of the preeminent AI mass-tourism destination in the world; thus, Antalya is the best study setting for understanding destination image formation among tourists preferring a destination due to AI product offerings.

\section{Method}

This study utilises Asymmetric Impact Performance Analysis (AIPA) to analyse the cognitive factors affecting overall destination image perceptions among tourists visiting Antalya, famous for its AI mass tourism products. AIPA is used to test both the effects of cognitive destination attributes that are effective on the overall destination image perception of tourists in a model as well as perceptual differences between male and female tourists, with AIPA matrices for each gender. The results of the analysis may provide valuable insights identifying cognitive factors that are important for overall destination image evaluations from tourists, especially for mass tourism destinations like Antalya.

Kano et al. (1984) argue that the effects of product characteristics on customer satisfaction can be grouped in five categories: basic, performance, excitement, inverse and non-difference factors, considering the nonlinear effects of product characteristics on customer satisfaction. This theory, known as the Kano Model, helps researchers identify priority product characteristics that need to be developed for customer satisfaction. The model has recently been referred to as Three-Factor Theory because researchers generally do not consider inverse and non-difference factors. Three-Factor Theory considers nonlinear effects of product characteristics on customer satisfaction: basic, performance and excitement factors. Basic factors refer to the basic function of a product. Lack of basic factors cause dissatisfaction but do not cause increase in satisfaction when presented (Matzler et al., 2004). Customers consider basic factors to be the minimum requirements that must be met by businesses. Performance factors create satisfaction when presented and dissatisfaction when not presented to customers. There is a linear and positive relationship between the perceived performance of performance factors and customer satisfaction. Excitement Factors are the basic elements of customer satisfaction. If they are available and their performance is high, they create a high level of satisfaction. On the other hand, their absence does not create dissatisfaction. Excitement factors are features that are not requested or expected by customer, and this surprise element for the customer has the potential to create high satisfaction. 
Nonlinear relationships between product characteristics and customer satisfaction studied in research areas include health services (Mittal et al., 1998), banking (Matzler et al., 2004), online shopping platforms (Falk et al., 2010), tourism destinations (Füller \& Matzler, 2008) and websites (Kim \& Fesenmaier, 2008). For example, Cheung and Lee (2009), who examine the nonlinear relationship between website information quality and user satisfaction, find that three of the four information quality features had a higher impact on customer satisfaction than their positive performance. Researchers often use methods like the Kano Technique, Critical Incident Technique, Importance Matrix and Penalty-Reward Contrast Analysis to identify these three factors.

Penalty-Reward Contrast Analysis, developed by Brandt (1987), proposes dummy variable regression analysis to determine basic, performance and excitement factors. Many researchers (Albayrak \& Caber, 2013; Anderson \& Mittal, 2000; Matzler \& Sauerwein, 2002; Mikulic \& Prebezac, 2011) have used the relevant analysis technique to reveal the nonlinear effects of perceived performance of product characteristics on destination image. To perform Penalty-Reward Contrast Analysis, the performance values of each cognitive image feature are first coded to create dummy variables. The factor scores of the dimensions are obtained during the factor analysis to form dummy variables and are divided into three sections and coded as (o,1) for 'low performance', (1,0) for 'high performance' and (o,o) for 'medium-level performance'. Dummy variables are considered independent variables and overall destination image perception is a dependent variable. As a result of the analysis, two regression coefficients (one presenting the effect of the feature at low-performance level and the other presenting the effect of the feature at high-performance level) are obtained (Matzler et al., 2004, p. 274).

Dummy1: the dummy variable presenting the high-performance level.

Dummy2: the dummy variable presenting the low-performance level.

$\beta 1$ : the regression coefficient presenting the effect of feature on destination image perception at a highperformance level.

32: the regression coefficient presenting the effect of feature on destination image perception at a lowperformance level.

At the final stage, regression coefficients for high $\left(\beta_{1}\right)$ and low $\left(\beta_{2}\right)$ performance levels are compared for the classification of image perception. Classification rules are: if regression coefficients of the lowperformance level are higher than the high-performance level, factors are classified as 'basic'; if regression coefficients of the high-performance level are higher than the low-performance level, factors are classified as 'excitement'; if both coefficients are equal, these characteristics are classified as 'performance' (Füller \& Matzler, 2007, p. 121).

\section{Scale and Sample}

The measurement scale for the cognitive attributes of destination image utilised in this study is developed by Ceylan and Çizel (2018) and is proven to be invariant for three nationalities and across genders in another study by Ceylan, Cizel and Karakas (2020). Measurement invariance enables utilisation of the scale for British, German and Russian tourists and draws cross-cultural conclusions. The scale utilised in this research comprises 22 cognitive items that are grouped under seven parcels utilising the parceling technique (Hall et al., 1999; Landis et al., 2000; Matsugana, 2008; Stylidis et al., 2017).

Data was collected in Antalya Airport's international terminal during Summer 2017 and consisted of 802 British, 953 German and 953 Russian tourists departing to their respective source markets. Out of 2,708 respondents, 1,268 respondents $(46.8 \%)$ were male and $1,440(53.2 \%)$ were female. To reduce coverage 
error, the mall intercept method was utilised by the research team, which consisted of one of the authors and research assistants. Tourists were approached while waiting in the queue for check-in or at the gate for boarding flights departing to designated destinations. Random sampling error was mitigated by a larger sample size of 2,708 (sample size required $n=2,700$, at $99 \%$ confidence level, $\mathrm{p}=\mathrm{q}$, the margin of error 2.48\%, tourist population visiting Antalya in 2017: 13,057,000). Data collection was conducted under similar conditions and respondents were assured that participation was voluntary and that results were to remain anonymous. Respondents who agreed to take part in the survey were given a copy of the questionnaire in their respective language on a clipboard with a pen and asked to provide their responses according to the Likert 7-type measurement instrument. Data was collected for three months during summer 2017 from people of different nationalities to avoid common method bias.

Ceylan and Cizel (2018) indicate that the scale invariance test is a prerequisite for comparison between groups. The scale invariance of the measurement tools used in this study is based on nationality. All factors produced results higher than AVE (Average Variance Extracted) 0.50 and CR (Composite Reliability) 0.7 for analysis. The KMO (Kaiser- Meyer-Olkin) test ensures sufficient sample size for analysis and correlation between items, where 0.956 indicates that the data set of 2,708 respondents are suitable for factor analysis. Bartlett's sphericity test can ensure the sustainability and effectiveness of responses (Chi-Square: 424.326). The skewness between -2 and +2 is considered to be the acceptable limit ( 0.46 and 1.64) as proof of normal distribution. Cronbach's 0,928 alpha indicates excellent strength and proves reliability.

\section{Analysis and Findings}

In the first stage of analysis, the value of Cronbach Alpha was calculated as 0.929 for the reliability of data. $29.6 \%$ of the 2,708 participants were British, $35.2 \%$ were German and $35.2 \%$ were Russian. The mean age of the participants was 38.86 (SD: 12.88). 58.5\% of the participants were female and $41.5 \%$ were male.

The highest performance score was obtained for natural resources, with 5.89 and the lowest score was for political factors, with 5.40 (Table 1 ). To determine cognitive image factors that affect overall destination image perception among participants, linear regression analysis is first performed based on the assumption that there is a linear relationship between the performance of the related factors and the perception of overall destination image. The regression model was statistically significant (F: 435.458; p: o.001), yielding 52.9\% explanation of overall image. As per results of linear regression analysis, social environment had the highest effect on overall destination image $(\beta=0.245)$.

In the initial step, mean and standard deviation values of the cognitive image sub-dimensions presented above indicate that all sub-dimensions of cognitive image evaluations are above the mean value of 4 . In this study, dimension locations in the importance-performance diagram for all participants are presented in Figure 1. For the importance-performance analysis performed within the scope of this study, the evaluation averages of the participants regarding dimensions were used as the performance value. The correlation coefficient (the relationship between each cognitive image sub-dimension and overall image evaluation) is utilised to express the significance value. As a result of correlation analysis, a significant positive correlation was found in the general image evaluation of all dimensions. These results showed that the highest correlation value (o.656) is obtained from the social environment dimension. 
Table 1. Linear Relationship Between Destination Image of Cognitive Attitude Components

\begin{tabular}{lccll} 
& Mean & S. D. & Correlations & $\beta$ \\
\hline Natural Resources & 5.89 & 0.93 & $0.535^{* *}$ & $0.110^{* *}$ \\
General Infrastructure & 5.43 & 1.19 & $0.469^{* *}$ & $0.067^{* *}$ \\
Tourism Infrastructure & 5.65 & 1.07 & $0.612^{* *}$ & $0.140^{* *}$ \\
Touristic Attractions & 5.63 & 0.97 & $0.568^{* *}$ & $0.082^{* *}$ \\
Economic Factors & 5.42 & 1.24 & $0.595^{* *}$ & $0.220^{* *}$ \\
Political Factors & 5.40 & 1.23 & $0.438^{* *}$ & $0.035^{*}$ \\
Social Environment & 5.68 & 1.01 & $0.656^{* *}$ & $0.245^{* *}$ \\
\hline
\end{tabular}

Note: $\mathrm{R}^{2}=0.529, \mathrm{~F}=435.458(\mathrm{~N}: 2,708){ }^{*} \mathrm{p}<0.05{ }^{* *} \mathrm{p}<0.01$

IPA analysis results reveal that the factors that have satisfactory performance are social environment, tourism infrastructure, and tourist attractions. In other words, tourists care about these factors and perceive their current performances as high. The low-priority quadrant includes general infrastructure and political factors. The performance and importance of assessments of substances in this field are low. There is one factor positioned in a possible overkill (natural resources) and one factor positioned in a 'concentrate here' quadrant (economic factors).

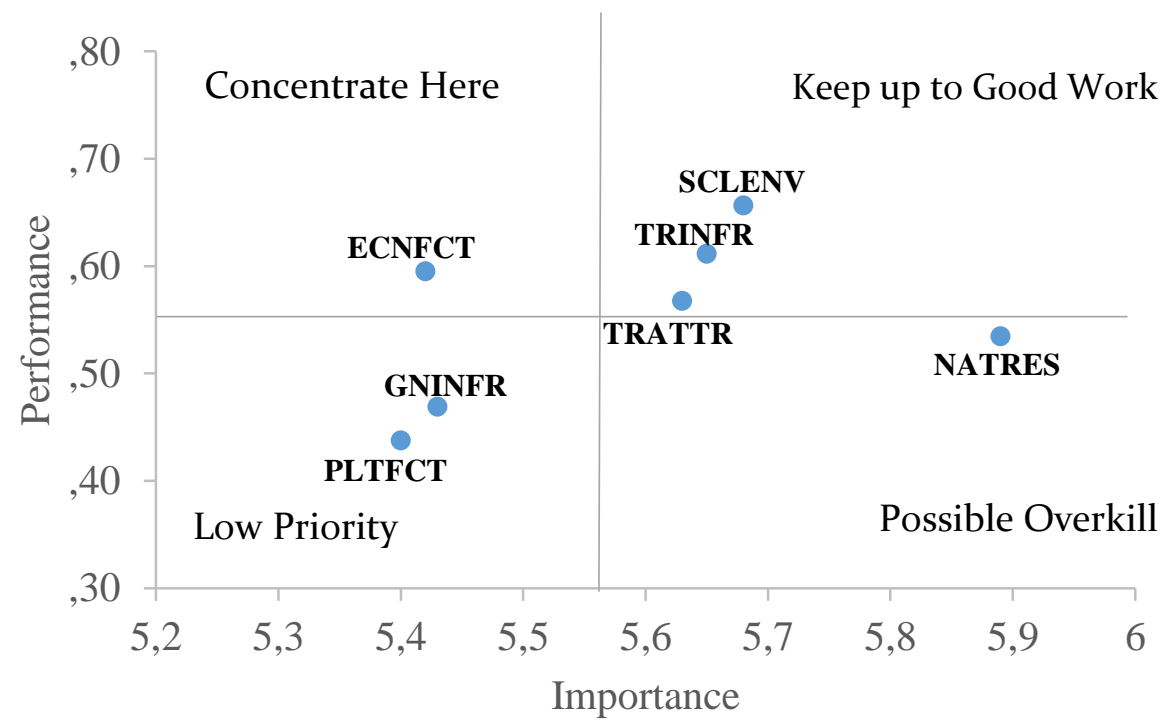

Note: $\quad$ Natural Resources: NATRES General Infrastructure: GNINFR Tourism Infrastructure: TRINFR Touristic Attractions: TRATTR
Economic Factors: ECNFCT

Political Factors: PLTFCT

Social Environment: SCLENV

Figure 1. Importance-Performance Analysis Result 
In the next stage, Penal-Reward Contrast Analysis is performed via dummy variable regression analysis based on the assumption that there was an asymmetric and nonlinear relationship between the performance of gender-based cognitive factors and the perception of overall destination image. A dummy variable regression is performed to determine whether impact below the expected level is different from impact above the expected level (Anderson \& Mittal 2000; Fuchs \& Weiermair, 2003; Matzler et al., 2006). This analysis aims to classify features as basic, performance, or excitement factors. Factor scores for each dimension obtained in factor analysis to form dummy variables were divided into three sections based on mean values, coded as $(0,1)$ for 'low-performance', $(1,0)$ for 'high-performance' and $(0,0)$ for 'medium-level' performance. Each dimension coded with two figures yield fourteen [(two dummy) $\mathrm{x}$ (seven dimensions)] dummy variables that are to be used as independent variables; overall destination image is used as the dependent variable and multivariate linear regression analysis is performed for both genders. As a result of this analysis, two different coefficients are obtained, reflecting the effect on overall destination image at low- and high-performance levels for each dimension (Table 2).

Coefficients obtained from dummy variable regression analysis reveal the importance of a feature's changes according to its level of performance. This finding is visualised in Figure 1 for an easier understanding of the coefficients. Characteristics that have a higher impact on overall destination image at low-performance levels are classified as 'basic factors'; characteristics that have a higher impact on overall image at high-performance levels are classified as 'excitement factors'; and characteristics that have approximately equal impact on overall image at high and low-performance levels are classified as 'performance factors' (Füller \& Matzler, 2007, p. 121).

The regression model is statistically significant for women (F: 68.513; p: 0.001) and the rate of explaining overall destination image is $45.7 \%$. The same model was also statistically significant for male participants (F: 99.149; p: o.0o1) and the rate of explaining overall destination image is $46.5 \%$. According to these findings, the factor having the highest impact on overall destination image among male participants is low-performance assessments of economic factors $(\beta=-0.410)$, while the factor having the highest impact on overall destination image for female participants is the low-performance impact of social environment $(\beta=-0.448)$.

Natural resources are classified as a 'basic' factor with a low-performance evaluation for males and has a higher impact, whereas the same dimension is classified as a 'performance' factor for females because both its low- and high-performance levels have nearly same impact. General infrastructure is classified as an 'excitement' factor for males because it does not have a significant impact on low-performance perception, whereas it is a 'basic' factor for females because it does not have a significant impact on high-performance perception.

Tourism infrastructure is classified as a 'basic' factor for males because its low-performance evaluation has a higher impact, and as an 'excitement' factor for females because it has a higher effect on highperformance level. Touristic attractions are classified as a 'basic' factor for males because their lowperformance level has a higher impact, and as a 'basic' factor for females because their high-performance perception does not have a significant effect. The economic factors dimension is classified as a 'basic' factor for males due to its lack of effect on the perception of high-performance level, and as a 'basic' factor for females because its perceived low-performance level has a higher impact. Political factors are defined as a 'performance' factor for males because both its high- and low-performance levels have no significant effect, and as a 'basic' factor for females because high-performance level does not have a significant effect. 
Table 2. Gender-Based Classification of Cognitive Attitude Components- Dummy Variable Regression Analysis

\begin{tabular}{|c|c|c|c|c|c|c|}
\hline & \multicolumn{2}{|l|}{ Male } & \multicolumn{2}{|l|}{ Female } & \multirow[b]{2}{*}{ High Level } & \multirow[b]{2}{*}{ Classification } \\
\hline & Low Level & High Level & Classification & Low Level & & \\
\hline $\begin{array}{l}\text { Natural } \\
\text { Resources } \\
\text { (NATRES) }\end{array}$ & $-0.332^{* *}$ & 0.108 & Basic & $-0.198^{*}$ & $0.205^{* *}$ & Performance \\
\hline $\begin{array}{l}\text { General } \\
\text { Infrastructure } \\
\text { (GNINFR) }\end{array}$ & -0.053 & $0.179^{* *}$ & Excitement & $-0.152^{*}$ & 0.101 & Basic \\
\hline $\begin{array}{l}\text { Tourism } \\
\text { Infrastructure } \\
\text { (TRINFR) }\end{array}$ & $-0.28 \mathrm{o}^{* *}$ & $0.140^{*}$ & Basic & -0.090 & $0.206^{* *}$ & Excitement \\
\hline $\begin{array}{l}\text { Touristic } \\
\text { Attractions } \\
\text { (TRATTR) }\end{array}$ & $-0.172^{*}$ & $0.128^{*}$ & Basic & $-0.240^{* *}$ & 0.040 & Basic \\
\hline $\begin{array}{l}\text { Economic } \\
\text { Factors } \\
\text { (ECNFCT) }\end{array}$ & $-0.410^{* *}$ & 0.109 & Basic & $-0.345^{* *}$ & $0.298^{* *}$ & Basic \\
\hline $\begin{array}{l}\text { Political } \\
\text { Factors } \\
\text { (PLTFCT) }\end{array}$ & -0.077 & 0.070 & Performance & $-0.116^{*}$ & 0.064 & Basic \\
\hline $\begin{array}{l}\text { Social } \\
\text { Environments } \\
\text { (SCLENV) }\end{array}$ & $-0.272^{* *}$ & $0.252^{* *}$ & Performance & $-0.448^{* *}$ & $0.165^{*}$ & Basic \\
\hline
\end{tabular}

Note: Male: $R^{2}=0.457, F=68.513 /$ Female: $R^{2}=0.465, F=99.149{ }^{*} p<0.05{ }^{* *} p<0.01$

The social environment dimension is defined as a 'performance' factor for males because low- and highperformance levels have a similar effect, and as a 'basic' factor for females because low-performance level has a higher impact. Considering the above evaluations, it is clear that gender has a significant role in classification of factors as basic, performance or excitement. 


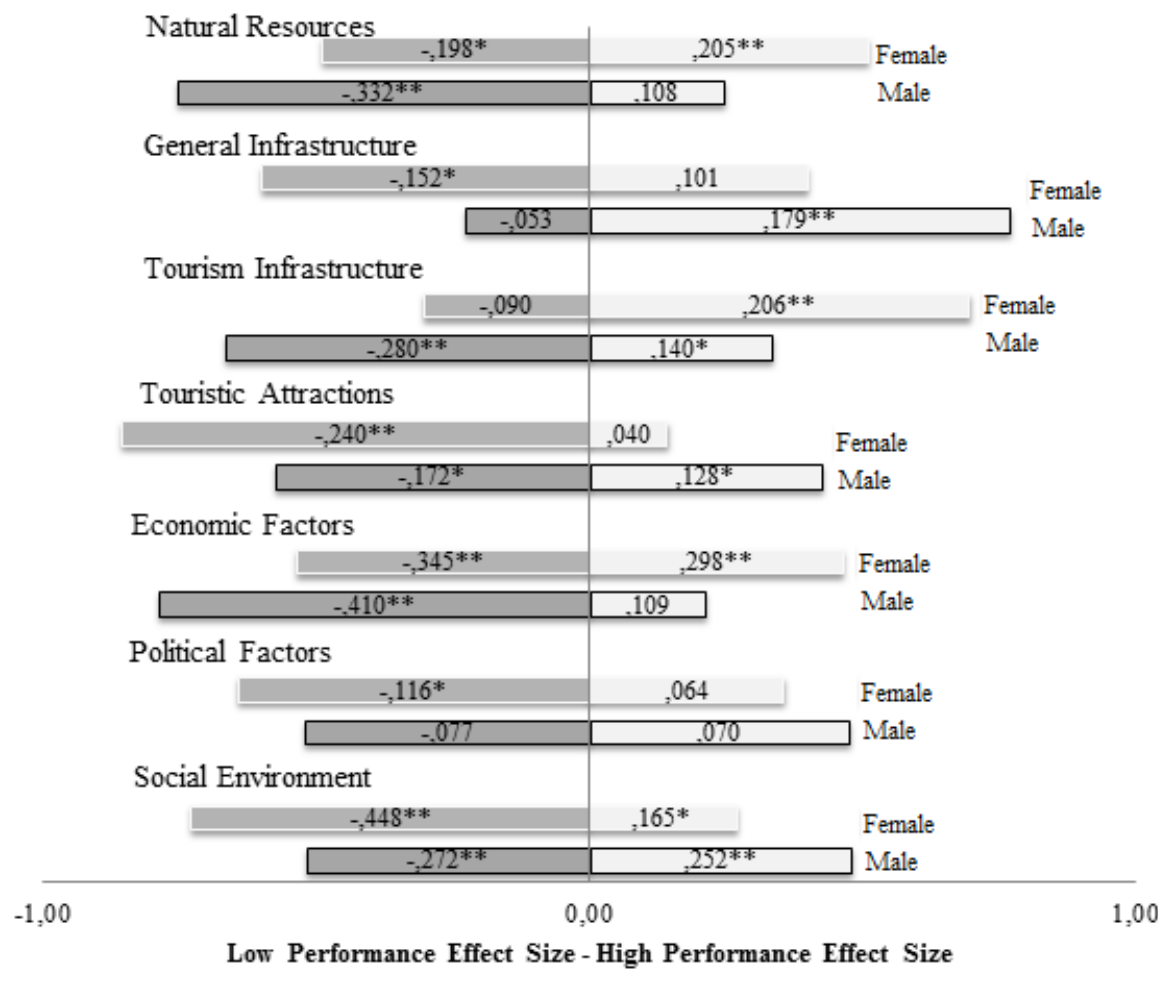

Note: Penalty and reward indices are standardized regression coefficients. ${ }^{*} \mathrm{p}<0.05,{ }^{* *} \mathrm{p}<0.01$.

Figure 2. Asymmetric Impact of Attribute-Level Performance on Destination Image

\section{Conclusions}

As a result of linear regression analysis, social environment, which is determined to be the most important feature, is classified as 'performance' for males and 'basic' for females when considered as an asymmetric relationship in terms of gender. When the performance level of an attribute is low for female tourists, the perception of overall destination image is negatively affected. However, improving the performance of the attribute does not generate an added value to overall destination image. For male tourists, both high and low performance has a similar impact in opposite directions. Therefore, improving the performance of a social environment will have a positive effect on the overall perception of image.

On the other hand, the regression analysis political factors, which have the lowest effect on overall destination image perception, defines them as 'performance' factors because they do not change with low or high performance for males. Therefore, increasing the performance of this attribute does not have a significant effect on the overall image perception among males. On the other hand, political factors being classified as a 'basic' factor by females reveals that increase in performance does not have a significant effect, while decrease in performance leads to a negative evaluation of the overall image.

General infrastructure is classified as an 'excitement' factor for males and as a 'basic' factor for females. While the decrease in general infrastructure performance causes negative evaluations from females, it does not have a significant effect on males. On the other hand, increase in performance causes positive evaluation from males but does not have a significant effect on females. 
Tourism infrastructure is classified as a 'basic' factor for male tourists and as an 'excitement' factor for female tourists. The results show that declining tourism infrastructure performance has a greater impact than increasing performance for males, whereas declining performance has no significant effect on the destination image among females, but the increase has a significant effect.

Natural resources are categorised as 'basic' factors for males and as 'performance' factors for females. Improvement of natural resources does not have a significant impact on males, while deterioration adversely affects image evaluation. For females, because positive and negative assessment have the same effect, sustaining performance will have a positive effect on image perception.

Tourist attractions are classified as a 'basic' factor for both male and female tourists. However, low performance for male tourists leads to a negative assessment, while high performance may result in a positive assessment. Alternatively, high performance does not have a meaningful effect for female tourists, and decreasing performance negatively affects destination image perception.

Economic factors are classified as 'basic' for both male and female tourists. A distinction is that low performance for female tourists leads to a negative assessment and high performance may result in a positive assessment, whereas increasing performance for male tourists does not have a meaningful effect and decrease in performance negatively affects destination image perception.

\section{Discussion}

Many destination image studies have analysed cognitive perceptions focusing on the tangible characteristics of a destination (Beerli \& Martin, 2004a, 2004b; Lin et al., 2018; Pearce, 1982). It is recommended that measurement of destination image be made geographically by considering tourism types, products, and service characteristics of a destination (Rakic \& Chambers, 2012). This study, using the Kano Model (1984), can help identify the characteristics that require development by using the linear and nonlinear effects of each of the cognitive features that affect the overall destination image perception of tourists in Antalya and to produce strategies that will make the most suitable use of the destination's potential (Pike \& Ryan, 2004; Stylidis et al., 2017).

Kano et al. (1984) propose Three-Factor Theory for considering the nonlinear effects of product characteristics on customer satisfaction leading to classification - categorised as basic, performance and excitement factors (Matzler et al., 2004). Basic factors cause dissatisfaction when not presented to customers, but do not cause satisfaction when presented. Customers consider basic factors to be minimum requirements that must be met by businesses. Therefore, to meet customer expectations the performance levels of all basic factors must be satisfied. Out of seven factors, only tourist attractions and economic factors are perceived as basic factors by both females and males. Even though these two factors are classified similarly, the reasons behind this classification are distinct, and include the potential for the high performance of tourist attractions to create a positive impact on males, whereas these attractions cannot create added value for females. Therefore, targeting male tourists can create a higher impact, but targeting tourist attractions to females may not be an efficient use of resources. Although both female and male tourists perceive economic factors as basic, aiming to satisfy female tourists may have a higher impact. The high-performance perception of economic factors in Antalya, an AI tourism destination, is not surprising due to the cost efficiency of AI ecosystems. Any performance deterioration in economic factors signals high dissatisfaction; thus, AI holiday package prices are to be closely monitored. This finding supports the continuation and growth of AI products in Antalya for optimising cost efficiency. 
Performance factors create satisfaction when presented and dissatisfaction when not presented to customers. There is a linear relationship between perceived performance of customer satisfaction and performance factors. The higher the performance of these characteristics, the higher customer satisfaction will be. There are only three characteristics perceived as performance factors and none of these are common between females and males. Female tourists perceive natural resources as performance factors, whereas male tourists perceive political factors and social environments as performance factors. However, the reasons for classification as performance factors for these three characteristics are not similar. Female tourists perceive natural resources as performance factors due to their meaningful impact on the quality of their holiday experiences; therefore, preserving natural resources is important for a destination to attract more female tourists. Male tourists perceive political features as performance factors due to their lack of influence on their destination choice. AI packages assure secure zones for tourists; therefore, male tourists' perceptions of political factors lack importance for destination choice under the protective umbrella of an AI system. On the other hand, male tourists perceive social environment as a performance factor due to its meaningful impact on the holiday experience. Thus, socialisation is an important criterion for male tourists and the efficiency of social activities should be enhanced. These three characteristics are perceived as basic factors for both genders. Natural resources for male tourists and political factors and social environment for female tourists are perceived as basic and prerequisite for holiday packages. The assurance provided by AI holiday packages enables the alignment of male and female destination preferences.

Excitement factors are key elements of customer satisfaction. If they exist and have high performance, they create a high level of satisfaction. On the other hand, if they do not exist, they do not create dissatisfaction. Excitement factors are features that are not requested or expected by customers, and this surprise element has the potential to create high satisfaction (Matzler et al., 1996; Sauerwein et al., 1996; Ting \& Chen, 2002). Kano's model, used in this research, is successful in revealing excitement factors. There are two characteristics of Antalya that are perceived as excitement factors, yet this perception is not shared by both genders. Tourism infrastructure is a basic factor for male tourists and an excitement factor for female tourists. Male tourists request tourism infrastructure as a minimum requirement whereas female tourists praise the family holiday features provided at the destination for relieving mothers and allowing them to enjoy more independent time. Kids clubs, animation for kids, and a wide variety of source market languages spoken at holiday facilities pamper kids and provide space for mothers. Additionally, health care services and secure kid zones within facilities provide assurance. Similarly, teenage activities nurture young adults' fun and sun activities within the secure perimeters of the holiday facility, requiring less supervision from parents.

Male tourists perceive general infrastructure as an excitement factor and female tourists perceive it as basic factor. As a mirror image of tourism infrastructure, male and female tourists have interchanging priorities and expectations from an AI holiday in Antalya. Female tourists expect smooth transportation to and from the airport, direct flights and convenient flight schedules to the destination, and constant internet and telecommunication access as basic factors at the time of an AI holiday package purchase. Male tourists see these general infrastructure features of Antalya as high-performance, positive surprise elements enhancing their holiday experience. Considering the repeat guest profile of Antalya, female tourists may not perceive tourist infrastructure as an excitement factor, and male tourists may not perceive general infrastructure as an excitement factor in the mid-to-long run. Nevertheless, these factors may continue to be the reason for positive word of mouth and may ensure further revisit intentions. Destination management organisations must be careful in preserving and enhancing tourist and general infrastructure to ensure high performance because a lack of basic factor performance leads to deterioration in holiday experiences, and thus satisfaction and loyalty. 
Mass tourism destinations working with AI systems are under intense competitive pressure and should monitor, preserve and enhance cognitive attributes affecting tourists' overall destination image perceptions, whether these attributes are basic, excitement, or performance factors. Successful implementations by destinations can be easily cross-fertilised by competitors and the quality of products and services can be easily noticed by tourists comparing destinations. Therefore, excitement factors, which provide potential for customer satisfaction, should be determined, created, implemented and monitored according to changes in tourists' image perceptions of destinations.

Destination image reflects a person's beliefs, ideas, feelings, expectations and impressions about a place (Kotler, 2002) and may vary depending on the socio-demographic characteristics of tourists. Destination attributes that lead to customer satisfaction (excitement factors) or dissatisfaction (basic factors) were examined in this research, accounting for different perceptions between genders. This gender perspective reveals that an attribute seen as a basic factor for females can be a performance or excitement factor for males, or vice versa. These results support the idea that destination promotion and marketing studies should be differentiated by gender (Beerli \& Martin, 2004).

\section{Limitations and Recommendations for Future Studies}

The research findings provide important information for destination management organisations by classifying the asymmetric effects of each cognitive destination attitude component on the overall destination image, based on gender. In future studies, the asymmetric effect of the cognitive destination attribute on the overall destination image can be compared according to factors such as generation, nationality and culture. This study also has limitations that may shed light on the design of future research. First, only cognitive attitude components were examined in this study. Cognitive, affective, and conative destination attitude components that affect the destination image can be considered together in future studies. Second, this study is cross-sectional; therefore, it would be incorrect to establish and generalise true cause and effect relationships without longitudinal data. Therefore, in future studies, longitudinal research may be proposed for different tourism destinations and different tourism product types. Third, the cognitive attitudes of tourists towards the destination image were measured perceptually, using a questionnaire. In future studies, user-generated content can be used as a data source. Also, it may be wise to use a mixed method to explain why excitement, performance and basic factors have transformed over time.

\section{References}

Agapito, D., Oom do Valle, P., \& da Costa Mendes, J. (2013). The Cognitive-Affective-Conative Model of Destination Image: A Confirmatory Analysis. Journal of Travel E Tourism Marketing, 30(5), 471481. https://doi.org/10.1080/10548408.2013.803393

Aguiló, E., Alegre, J., \& Sard, M. (2005). The persistence of the sun and sand tourism model. Tourism Management, 26(2), 219-231. https://doi.org/10.1016/j.tourman.2003.11.004

Albayrak, T., \& Caber, M. (2013). The symmetric and asymmetric influences of destination attributes on overall visitor satisfaction. Current Issues in Tourism, 16(2), 149-166. https://doi.org/10.108o/13683500.2012.682978

Anand, P., Holbrook, M.B., \& Stephens, D. (1988). The Formation of Affective Judgments: The Cognitive-Affective Model Versus the Independence Hypothesis. Journal of Consumer Research, 15(3), 386-391. https://doi.org/10.1086/209176

Anderson, E.W., \& Mittal, V. (2000). Strengthening the satisfaction-profit chain. Journal of Service research, 3(2), 107-120.

Andrews, H. (2005). Feeling at home: Embodying Britishness in a Spanish charter tourist resort. Tourist Studies, 5(3), 247-266. 
Aranson, E., Wilson, T. D. \& Akert, R. M. (2010). Sosyal Psikoloji (translator O. Gündüz), (Social Psychology). Kaktüs publications.

Ash, J., \& Turner, L. (1976). The golden hordes: International tourism and the pleasure periphery. New York: St. Martin's Press.

Baloglu, S., \& McCleary, K. W. (1999). A model of destination image formation. Annals of tourism research, 26(4), 868-897. https://doi.org/10.1016/So160-7383(99)0oo30-4

Baloglu, S., Pekcan, A., Chen, S.L., \& Santos, J. (2004). The Relationship Between Destination Performance, Overall Satisfaction, and Behavioral Intention for Distinct Segments. Journal of Quality Assurance in Hospitality \& Tourism, 4(3-4), 149-165. https://doi.org/10.1300/J162vo4no3_10

Beerli, A., \& Martin, J.D. (2004a). Tourists' characteristics and the perceived image of tourist destinations: a quantitative analysis-a case study of Lanzarote, Spain. Tourism Management, 25(5), 623-636. doi: 10.1016/j.tourman.2003.06.004

Beerli, A., \& Martin, J.D. (2004b). Factors influencing destination image. Annals of Tourism Research, 31(3), 657-681. doi: 10.1016/j.annals.2004.01.010

Birkan, I. (2004). All-inclusive is neither a disaster nor a savior, it's a system. Resort Turizm ve Seyahat Dergisi, 18, 18-20.

Bowen, D. (2001). Antecedents of consumer satisfaction and dis-satisfaction (CS/D) on long-haul inclusive tours-a reality check on theoretical considerations. Tourism Management, 22(1), 49-61. doi: 10.1016/So261-5177(0o)ooo22-4

Bramwell, B. (Ed.). (2004). Coastal mass tourism: Diversification and sustainable development in Southern Europe. Channel View Publications.

Brandt, R.D. (1987). A procedure for identifying value-enhancing service components using customer satisfaction survey data. Add Value to Your Service, 6, 61-65.

Ceylan, D., \& Cizel, B. (2018). Testing destination image scale invariance among British, German and Russian tourists: A multi-group confirmatory factor analysis. Advances in Hospitality and Tourism Research Journal ,6(2), 119-146. doi: 10.30519/ahtr.449176

Ceylan, D., Çizel, B., \& Karakaş, H. (2020). Testing destination image scale invariance for intergroup comparison. Tourism Analysis, 25, 239-251.

Cheung, C. M., \& Lee, M. K. (2009). User satisfaction with an internet-based portal: An asymmetric and nonlinear approach. Journal of the American Society for Information Science and Technology, 6o(1), 111-122.

Cizel, R.B., Cizel, B., Sarvan, F., \& Ozdemir, B. (2013). Emergence and Spread of an All-Inclusive System in the Turkish Tourism Sector and Strategic Responses of Accommodation Firms. International Journal of Hospitality \& Tourism Administration, 14(4), 305-340. doi:10.1080/15256480.2013.838083

Cohen, E. (1972). Toward a sociology of international tourism. Social Research, 39, 164-172.

Crompton, J. L. (1977). A systems model of the tourist's destination selection decision process with reference to the role of image and perceived constraints. College Station: Texas A \& M University. Unpublished Ph.D. dissertation.

Demir, M., \& Demir, S.S. (2001). Hersey dahil (all-inclusive) pansiyon türü uygulamasinin konaklama isletmeleri, personel, müsteriler, seyahat acentalari ve bölgedeki diger isletmeler açisindan olumlu ve olumsuz yönlerinin analizi [Analysis of the positive and negative aspects of the all-inclusive hostel type application in terms of accommodation businesses, staff, customers, travel agencies and other businesses in the region]. Maltepe Üniversitesi Turizm Arastırmaları Dergisi, 1(1), 67-100.

Falk, T., Hammerschmidt, M., \& Schepers, J. J. (2010). The service quality-satisfaction link revisited: exploring asymmetries and dynamics. Journal of the Academy of Marketing Science, 38(3), 288-302.

Fuchs, M., \& Weiermair, K. (2003). New perspectives of satisfaction research in tourism destinations. Tourism Review, 58(3), 6-14. 
Füller, J., \& Matzler, K. (2008). Customer delight and market segmentation: An application of the threefactor theory of customer satisfaction on life-style groups. Tourism Management, 29(1), 116-126. doi: 10.1016/j.tourman.2007.03.021

Gartner, W.C. (1993). Image Formation Process. In: M Uysal \& D Fesenmaier (Eds.), Communication and Channel Systems in Tourism Marketing (pp. 191-215). The Haworth Press.

Gursoy, D., Chen, J., \& Chi, C. (2014). Theoretical examination of destination loyalty formation. International Journal of Contemporary Hospitality Management, 26(5), 809-827. doi:10.1108/ijchm12-2013-0539

Gursoy, D., Chi, C.G., \& Dyer, P. (2010). Locals' attitudes toward mass and alternative tourism: The case of Sunshine Coast, Australia. Journal of Travel Research, 49(3), 381-394. doi: 10.1177/0047287509346853

Hall, R.J., Snell, A.F., \& Foust, M.S. (1999). Item Parceling Strategies in SEM: Investigating the Subtle Effects of Unmodeled Secondary Constructs. Organizational Research Methods, 2(3), 233-256. doi:10.1177/109442819923002

Heung, V.C.S., \& Chu, R. (2000). Important factors affecting Hong Kong consumers' choice of a travel agency for all-inclusive tours. Journal of Travel Research, 39(1), 52-59.

Hilgard, E.R. (1980). The trilogy of mind: Cognition, affection and conation. Journal of the History of the Behavioral Sciences, 16, 107-117. doi.org/10.1002/1520-6696(198004)16:2<107: AIDJHBS2300160202>3.0.CO;2-Y

Issa, J., \& Jayawardena, C. (2003). The "all-inclusive" concept in the Caribbean. International Journal of Contemporary Hospitality Management, 15(3), 167-171. doi: 10.1108/09596110310470211

Kano, N., Seraku, N., Takahashi, F., \& Tsuji, S. (1984). Attractive quality and must-be quality. Hinshitsu, The Journal of the Japanese Society for Quality Control, 14, 39-48.

Kim, H., \& Fesenmaier, D.R. (2008). Persuasive design of destination web sites: An analysis of first impression. Journal of Travel Research, 47(1), 3-13. doi: 10.1177/0047287507312405

Kotler, P. (2002). Marketing Management. Prentice Hall.

Landis, R.S., Beal, D.J., \& Tesluk, P.E. (2000). A comparison of approaches to forming composite measures in structural equation models. Organizational Research Methods, 3(2), 186-207. doi: $10.1177 / 109442810032003$

Lee, G., \& Lee, C.K. (2009). Cross-cultural comparison of the image of Guam perceived by Korean and Japanese leisure travelers: Importance-performance analysis. Tourism Management, 30(6), 922931. doi: 10.1016/j.tourman.2008.11.013

Lin, Z., Vlachos, I., \& Ollier, J. (2018). Prioritizing destination attributes for optimal resource allocation: a study of Chinese tourists visiting Britain. Journal of Travel E Tourism Marketing, 35(8), 1013-1026. doi:10.1080/10548408.2018.1468854

Litvin, S.W., \& Ling, S.N.S. (2001). The destination attribute management model: an empirical application to Bintan, Indonesia. Tourism Management, 22(5), 481-492. doi: 10.1016/So2615177(01)0ooo3-6

Matsunaga, M. (2008). Item parceling in structural equation modeling: A primer. Communication Methods and Measures, 2(4), 260-293. doi:10.1080/19312450802458935

Matzler, K., \& Sauerwein, E. (2002). The factor structure of customer satisfaction. International Journal of Service Industry Management, 13(4), 314-332. doi: 10.1108/09564230210445078

Matzler, K., Fuchs, M., \& Schubert, A. (2004). Employee satisfaction: does Kano's model apply? Total Quality Management \& Business Excellence, 15(9-10), 1179-1198. doi: 10.1080/1478336042000255569

Menekse, R. (2005). Evaluation of all-inclusive system and its effects on the beneficiaries from the perspective of the hotel managers. Ekonomik ve Sosyal Arastırmalar Dergisi, 1, 94-127.

Mikulic, J., \& Prebezac, D. (2011). A critical review of techniques for classifying quality attributes in the Kano Model. Managing Service Quality, 21(1), 46-66. 
Ministry of Culture and Tourism (2020). Tourism Revenues and Expenses - Turkey (2017-2020). https://yigm.ktb.gov.tr/TR-201116/turizm-gelirleri-ve-giderleri.html/15.09.2019

Mittal, V., Ross, Jr. W.T., \& Baldasare, P.M. (1998). The asymmetric impact of negative and positive attribute-level performance on overall satisfaction and repurchase intentions. Journal of Marketing, 62(1), 33-47.

Ostermaier, R. (2003). Her Şey Dahil Hem Türkiye, Hem Tur Operatörleri İçin Önemli Bir Araçtır [All Inclusive is an important tool for both Turkey and Tour Operators]. Resort Turizm ve Seyahat Dergisi, 10, 16-17.

Pearce, P.L. (1982). Perceived changes in holiday destinations. Annals of Tourism Research, 9(2), 145164. doi:10.1016/0160-7383(82)90044-5

Pike, S. (2002). Destination image analysis-a review of 142 papers from 1973 to 200o. Tourism Management, 23(5), 541-549. doi:10.1016/so261-5177(02)oooo5-5

Pearce, P.L. (2005). Tourist behaviour: Themes and conceptual schemes. Channel View Publications.

Pike, S. (2009). Destination brand positions of a competitive set of near-home destinations. Tourism Management, 30(6): 857-866. doi: 10.1016/j.tourman.2008.12.007

Pike, S., \& Ryan, C. (2004). Destination Positioning Analysis through a Comparison of Cognitive, Affective, and Conative Perceptions. Journal of Travel Research, 42(4), 333-342. doi: 10.1177/0047287504263029

Poon, A. (1998). All-inclusive resorts. Travel and Tourism Analyst, 6, 62-77.

Poon, A. (2003). Competitive strategies for a 'new tourism'. In C P Cooper (Eds.) Classic Reviews in Tourism (pp. 130-142). Channel View Publications.

Rakić, T., \& Chambers, D. (2012). Rethinking the consumption of places. Annals of Tourism Research, 39(3), 1612-1633. doi: 10.1016/j.annals.2011.12.003

Russell, J.A., \& Pratt, G. (1980). A description of the affective quality attributed to environments. Journal of Personality and Social Psychology, 38(2), 311-322.

Sauerwein, E., Bailom, F., Matzler, K., \& Hinterhuber, H. H. (1996, February). The Kano model: How to delight your customers. In International Working Seminar on Production Economics,1(4), 313-327.

Smith, V.L. (1977). Hosts and guests: The anthropology of tourism. University of Pennsylvania Press.

Smith, W.W., Li, X., Pan, B., Witte, M., \& Doherty, S.T. (2015). Tracking destination image across the trip experience with smartphone technology. Tourism Management, 48, 113-122. doi: 10.1016/j.tourman.2014.04.010

Stern, E., \& Krakover, S. (1993). The Formation of a Composite Urban Image. Geographical Analysis, 25(2), 130-146. doi:10.1111/j.1538-4632. 1993.tboo285.X

Stylidis, D., Shani, A., \& Belhassen, Y. (2017). Testing an integrated destination image model across residents and tourists. Tourism Management, 58, 184-195. doi: 10.1016/j.tourman.2016.10.014

Stylos, N., \& Bellou, V. (2018). Investigating Tourists' Revisit Proxies: The Key Role of Destination Loyalty and Its Dimensions. Journal of Travel Research, 58(7), 1123-1145. doi: 10.1177/0047287518802100

Stylos, N., Vassiliadis, C.A., Bellou, V., \& Andronikidis, A. (2016). Destination images, holistic images and personal normative beliefs: Predictors of intention to revisit a destination. Tourism Management, 53, 40-60. doi: 10.1016/j.tourman.2015.09.006

Stylos, N., Bellou, V., Andronikidis, A., \& Vassiliadis, C.A. (2017). Linking the dots among destination images, place attachment, and revisit intentions: A study among British and Russian tourists. Tourism Management, 6o, 15-29. doi: 10.1016/j.tourman.2016.11.006

Ting, S.C., \& Chen, C.N. (2002). The asymmetrical and non-linear effects of store quality attributes on customer satisfaction. Total Quality Management, 13(4), 547-569. doi: 10.108o/o9544120220149331

Truong, T.H., \& King, B. (2009). An evaluation of satisfaction levels among Chinese tourists in Vietnam. International Journal of Tourism Research, 11(6), 521-535. doi: 10.1002/jtr.726 
Uner, M.M., Sokmen, A., \& Birkan, I. (2006). Türkiye'de hersey dahil uygulamasinin konaklama isletmeleri üzerindeki etkisi: Antalya ornegi [Influence of all-inclusive system in the Turkish hspitality industry]. Anatolia: Turizm Arastırmaları Dergisi, 17(1), 35-50.

Unguren, E., Cengiz, F., \& Algur, S. (2009). İş tatmini ve örgütsel çatışma yönetimi arasındaki ilişkinin belirlenmesi: konaklama işletmeleri üzerinde bir araştırma [The research about determination of the relationship between job satisfaction of employees and organizational conflict in hospitality Industry]. Elektronik Sosyal Bilimler Dergisi, 8(27), 36-56.

Vainikka, V. (2013). Rethinking mass tourism. Tourist Studies, 13(3), 268-286. doi: 10.1177/1468797613498163

Voss, K. (2003). Herşey dahil geçici bir trend degil [All-inclusive is not a temporary trend]. Resort Turizm ve Seyahat Dergisi, 10, 14.

Wong, C.S., \& Kwong, W.Y.Y. (2004). Outbound tourists' selection criteria for choosing all-inclusive package tours. Tourism Management, 25(5), 581-592. doi: 10.1016/j.tourman.2003.06.002

Zhang, M., Zhang, G., Gursoy, D., \& Fu, X. (2018). Message framing and regulatory focus effects on destination image formation. Tourism Management, 69, 397-407. doi: 10.1016/j.tourman.2018.06.025

Received: 10/06/2020

Accepted: 04/11/2020

Coordinating editor: Estela Mariné Roig 